Niniejsza publikacja jest dostępna na licencji Creative Commons. Uznanie autorstwa-Użycie niekomercyjne-Bez utworów zależnych 3.0 Polska. Pewne prawa zastrzeżone na rzecz autora. Zezwala się na wykorzystanie publikacji zgodnie z licencja - pod warunkiem zachowania niniejszej informacji licencyjnej oraz wskazania autora jako wtaściciela praw do tekstu. Treść licencji jest dostęna na stronie: http://creativecommons.org/licenses/by-nc-nd/3.0/pl/

Lingwistyka Stosowana 21: 1/2017, 39-53

\author{
Elżbieta JENDRYCH \\ Koźmiński University
}

\title{
Metaphoric Expressions in Business Communication
}

\begin{abstract}
:
Figurative language has always been used in business communication, with metaphoric expressions being its most representative and frequent elements. Metaphor is defined as a transference of the literal meaning of a word into another context, which means that one thing is described in terms of some other thing (M. Long/ J. Richards 1999), e.g. time is money, cash cow, sleeping beauty. It is the notion of either comparison or resemblance that creates the basis for metaphor - instead of the literal meaning of a word or expression native language users can easily produce a metaphoric expression and understand its figurative meaning. Metaphors are culture-specific and they reveal patterns of thought that are characteristic of individuals and of groups (G. Lakoff/ M. Johnson 1980). Business English metaphors can, and indeed do, reflect the values, beliefs and norms that prevail in the language of business communication in English-speaking countries and in many global companies in which English is a lingua franca. Figurative expressions are frequently found to be the preferred way of conveying meaning and business communicators tend to use metaphoric expressions both in written and spoken discourse. In this study popular standard business metaphors were excerpted by hand from three dictionaries: Cambridge Business English Dictionary and Thesaurus, Longman Business English Dictionary (2007), and Oxford Collocations Dictionary (2008). It was arbitrarily assumed that the inclusion of a metaphor into one or more of these dictionaries suggests that it is considered to be a standard ('dead') business metaphor. The excerpted metaphors were classified (1) formally, i.e. according to the structure of a given metaphor and (2) semantically, i.e. according to the concept which underlies a given metaphor. The paper also gives examples of 'living' (novel) business metaphors excerpted from a small, and therefore not representative, research corpus of articles published in "The Wall Street Journal" on 25 February 2015. The aim of the presented examples of metaphors is to demonstrate how easily novel metaphors can be created. Then, the paper discusses the functions and characteristics of popular metaphors used in typical business situations. Finally, it identifies some of the challenges in metaphor understanding and metaphor usage faced by non-native speakers of business English.
\end{abstract}

\section{Introduction}

Today metaphors are generally accepted in the language of business communication and they are widely used in business discourse. Metaphor means transference of a word from one context into another; metaphor is described as "a means by which one thing is described in terms of something else" (M. Long/ J. Richards 1999: x). It is the notion of either comparison or resemblance that creates the basis for metaphor - instead of the literal meaning of words or expressions native language users can easily produce metaphors and understand their figurative meaning. Metaphors add variety, 
imagery, spice and colour to the language. Thanks to metaphors business English users can express their views, feelings and opinions in a stronger, and sometimes more emotional or persuasive way.

G. Lakoff and M. Johnson (1980) are of the opinion that metaphoric expressions reflect the metaphorical nature of the concepts that structure our everyday activities. They claim that most of the ordinary conceptual system people create is metaphorical in nature and that our cognition is metaphorical. Thus the conceptual system used in thinking is reflected in the conceptual system on which communication is based. Metaphors reveal patterns of thought that are characteristic of individuals and of groups. Some popular business metaphors, e.g. advertising campaign are used in many European languages. S. Thornbury says that people "resort to and depend on the use of metaphor when it comes to verbalizing their experience: metaphors help them to see what is invisible, to describe what otherwise would be indescribable" (1991: 193).

In the language of business communication, metaphors reflect the way of thinking. L. Cameron and G. Low in their book Researching and Applying Metaphor (1999) say that metaphor is fundamental to the way language systems develop over time and to the way human beings consolidate and extend their ideas about themselves, their relationships and their knowledge of the world. A classical Arabic saying that a metaphor is the bridge to reality seems to be true since metaphor "links and comprises the known and the unknown, the tangible and the less tangible, the familiar and the new" (M. Cortazzi/ L. Jin 1999: 149).

Longman Dictionary of Language Teaching and Applied Linguistics says that "metaphors are important means by which words carry both cultural and semantic meanings, and each language has its own metaphors that have been accumulated over time" (J. Richards/ R. Schmidt 2002: 201). This statement helps to explain why metaphoric expressions are widely used in business communication practice.

Metaphoric expressions have been extensively studied by psychologists, cognitive linguists, sociologists and philosophers but not by applied linguists. "While the role of metaphor in language has been a focus of considerable interest in linguistics and other fields since the pioneering work of Lakoff and Johnson and has been the focus of several thousand journal articles, it has received much less attention within applied linguistics" (M. Long/ J. Richards 1999: x).

The role of high-frequency metaphoric expressions in the language of business communication needs to be explored in greater detail. Analyses of these metaphoric expressions from the point of view of applied linguistics can shed some more light on the nature of business communication. The aim of the paper is to present the most popular business metaphors, to suggest a classification of these expressions, to analyze their most common classes and to identify their role in today's business communication. Firstly, the paper presents a list of selected high-frequency metaphors used in the language of business communication. The list is organized in two ways: (1) formally - according to the structure of metaphor, and (2) semantically - according to the concept underlying a given metaphor. These two categorizations are followed by examples of business metaphors excerpted from a corpus of articles published in the 
Wall Street Journal. Finally, selected qualities of business metaphors and the challenges some metaphors pose to non-native speakers are discussed.

\section{Formal classes of business metaphors}

Following H.G. Widdowson's principles of classification, we can say that "generally speaking, things are classified in linguistics in much the same way as they are classified everywhere else: on the basis of similarity (...). It is indeed of the very nature of language itself, as we have seen, that enables us to impose an order on things in the physical world by classifying them in conventionally convenient ways" (H.G. Widdowson 1996: 30).

The examples of popular business metaphors (excerpted from the following sources: Cambridge Business English Dictionary and Thesaurus - www: dictionary.cambridge.org/dictionary/british; Longman Business English Dictionary 2007; and Oxford Collocations Dictionary 2008) presented below are classified alphabetically according to their structure into the following formal categories: one-word metaphors and compounds, two-word metaphors of four groups (noun + noun metaphors, adjective + noun metaphors, verb + noun metaphors, verb + adjective/adverb metaphors) and finally, multi-word metaphors.

It is hoped that such a classification may contribute to a more detailed description of the most popular metaphors used in the language of business communication.

Category 1

- one-word metaphors:

anchor,

barometer, bubble, bundle,

cannibalization, cap, ceiling, coffers, cowboy,

dilemma, dog, dormant,

entrant,

fence, fleece, float, floor, flotation, flourish, flyer, friends,

gearing, ghost, giant, gilts,

hawk,

incubator, ink, intangibles,

jeep, jungle,

knock,

lemon, leverage, liaise, liquid, liquidity, listed, loaded,

magnate, maturity, mecca, melon, mushroom,

niche,

officer,

parachute, pet, prospect,

quotations,

recruit,

seconds, smurf, solvent, star, sweetener,

tangibles, the floor.

- compounds:

asset-stripping, 
backhander, ballpark, benchmark, boilerplate, bookbuilding, bootleg, bottleneck, brainstorming, breadwinner, brownfield, buzzword, cheerleader, cherry-picking, concert party, crowdsourcing, data-mining, down-market, down-shifter, deadhead, deadline, downtime, fan club, featherbedding, gatekeeper, go-slow, grapevine, greenback, greenfield, greenmail, greenwashing, guesstimate,

haircut, handshake, headcount, headhunter, heavyweight, horse-trading, hotdesking, hotline, kickback, king-size, knockoff,

letterhead, lifeboat, mailshot, money-grabbing, moneymaker, money-spinner, moonlight, near-shoring, networking, off-shoring, outsourcing, overshoot/undershoot, paper-pusher, pathfinder, powerhouse, price-cutting, redlining, rustbelt, sandbag, shortlist, spin-off, start-up, sweatshop, tombstone, troubleshooter, up-market, whistleblower, whitewashing. Category 2

- noun + noun metaphors:

alpha shares, angel investor, asset chopping, asset stripping,

baby bond, backroom boys, balloon loan, balloon mortgage, balloon payment, bank holiday, bank paper, barometer stock, bean counter, beauty parade, bear hug, bear market, bear raid, bear run, bear squeeze, bellwether bond, blanket ban, book runner, book value, bottom line, brand stretching, brain drain, bridge loan, bucket shop, buffer stock, bull market, bull run, bulldog market, bullet loan, business angel, business game, business park, buzz advertising, buzz group, buzz marketing,

cafeteria plan, capital flow, car pool, carbon credit, career ladder, career path, cash cow, cash crunch, cash flow, cash mountain, catchment area, category killer, ceiling price, chain store, comfort zone, compensation package, corporate ladder, cost leader, cowboy builder, credit freeze, credit squeeze, crown jewels,

daisy chain, danger money, daughter company, dawn raid, dead stock, deadweight cargo, debt instrument, debt retirement, decision tree, discount window, distribution channel, dole queue, dotcom company, dust bowl,

elevator pitch, equity kicker, escalator clause,

face value, factory floor, factory hand, field research, field staff, fire sale, flagship store, flight capital, flow production, food mountain, framework agreement, freeze agreement, fringe bank, fringe benefits,

ghost worker, giveaway price, glamour stock, glass ceiling, gold mine, gold rush, goodbye kiss, grace period, grandfather rights, graveyard market, graveyard shift, gravy train, growth area,

halo effect, harvesting strategy, head office, headline inflation, helicopter picture, highway robbery, household name, housing bubble, hush money, hygiene factor, 
infant industry, insider trading, investment vehicle,

January effect, job bank, job hunting, jungle telegraph, junk bond, junk mail,

key account, knockdown price,

lightening strike, line stretching, loan club, loan shark, lump labour, lump sum,

macaroni defense, maiden dividend, mail drop, management guru, margin buying, market basket, market floor, market mechanism, market niche, marketing blitz, marzipan layer, maturity date, media baron, media buyer, media mogul, milk round, mission statement, money laundering, mouse potato, mystery shopper,

nest egg,

office park,

package holiday, paper millionaire, parent company, pathfinder prospectus, pay freeze, pay squeeze, peak season, pen pusher, penetration pricing, people pill, pie chart, pirate station, plum job, poison pill, preference capital, press baron, price ceiling, price floor,

price freeze, price mechanism, price swings, price taker, problem child, product family, product lifecycle, product line, profit skimming, publicity stunt, push strategy, pyramid selling,

question mark,

rat race, repayment holiday, ring road, rocket scientist,

salami slicing, sales literature, sales push, sales war, Samurai bond, sandwich course, seed money, shadow economy, shadow market, shark repellent, shelf company, shoestring budget, shop floor, shop steward, Silicon Valley, sin tax, sister company, skimming pricing, sleeper stock, slush fund, snail mail, spice trader, street furniture, suicide pill, sunrise company, sunrise/sunset industry, sunset law, sunset sector, sunshine policy, supply chain,

tax bite, tax haven, tax holiday, tax loophole, tax shelter, tax threshold, teaser ad, threshold effect, trade mission, turnkey contract, twilight zone,

umbrella fund, umbrella organization,

value chain,

Wall Street, wash sale, whistle blowing, windfall profit, windfall tax, window dressing, window shopping.

Category 3

- adjective + noun metaphors:

acid ratio, acid test, active market, ailing economy,

back door, bad debt, bad guy, bad title, bare bones, Beige Book, big hitter, blind test,blue chips, boiler room, bottom line,

casual Friday, cheap/dear money, classified ad, clean hands, clean opinion, close company, closed shop, cold call, commercial paper, congested market, crawling inflation, creative accounting, creative selling, creeping inflation, creeping takeover,

dead season, deep discount, deep pockets, dirty float, dirty money, dormant account, Dutch action, Dutch bargain,

easy money, economic gateway, economic recovery, economic survival, economic tiger, emerging market, empty nesters, empty suit, exorbitant price, 
fallen angel, filthy lucre, flat demand, flat organization, flat price, flat tax, financial instrument, financial meltdown, financial standing, flexible hours, floor limit, friendly company, friendly merger, fresh money, frozen asset, frozen prices, funny money,

galloping inflation, global village,

hard asset, hard core, hard currency, hard/soft landing, hard sell, headed paper, heavy/light duty, heavy leverage, heavy selling, heavy share, heavy trading, high achiever, high flier, high performer, high season, high tech, horizontal/vertical integration, hot money,

idle money, inflated bubble, inflationary spiral, invisible trade,

late interest, lean organization, lean production, leveraged buyout, low season, low tech, long/short position,

massive lay-offs,

naked contract, naked writer, narrow market, narrow money, near money,

negotiable instrument, Nervous Nellie, new/old money, nude contract,

open account, open cheque, open outcry, open shop, order picking,

predatory pricing, prohibitive price, pure profit,

quick buck, quick ratio,

rising/falling market,

safe haven, scrambled merchandising, sharp practice, silent partner, sinking fund, sitting tenant, skyrocketing price, sleeping beauty, sleeping partner, sliding peg, slim majority, small print, smart card, soft currency, soft loan, soft market, soft price, soft sales, sound economy, spiralling cost, standing order, strategic decision, strategic partner, sweated labour,

Third World, tight budget, tight margin, top executives, umbrella fund, useful life,

viral marketing, visible trade, voodoo accounting, watered stock, weak dollar, weak economy, wet goods, wet lease, wide price.

Category 4

- $\quad$ verb + noun metaphors:

answer the phone,

be a steal, break the ice,

chair a meeting, change hands, cook the books, corner the market, cut costs, cut prices

enter the market,

face a challenge, face a risk, fiddle the books, flood the market, fly a kite, forge an agreement,

gain a foothold, gain ground, get the axe, get the sack, go bankrupt, go downhill, go downmarket, go downscale, grease the wheels,

hammer a compromise, hammer the market, head north/south, hit the economy, hit the jackpot, hold the line, jump ship,

keep the deadline,

launder money, lose ground, 
make a fortune, make a killing, make a mint, make money, make profits,

meet a deadline, meet a debt, meet a target, meet demand, meet the specification, pave the way, penetrate the market, play the market,

quote the price,

split the difference, square the books, strike gold,

take the chair, take the floor, take the minutes, talk shop, trigger sales,

undergo a facelift,

win a market.

Category 5

- verb + adjective /adverb metaphors:

be listed, be quoted, be shortlisted, break even,

fall flat,

go bare, go broke, go bust, go downhill, go Dutch, go global, go green, go long, go south, go private, go public, go slow, go under,

meet halfway,

nail down,

plough back,

swallow up,

turn private.

Category 6

- multi-word metaphors:

a deal on a handshake, against all odds, at the end of the day,

bargain-basement price, basket of currencies, be at arm's length, be at odds,

be at the edge of bankruptcy, be going places, be flat broke, be in the line of fire, be in line with, be in short supply, be in the rocks, be in the saddle, be knocked down, be locked in a battle, be on the hook, be on the line, be open to offers, be out of pocket, be paid on the lump, be sitting on a goldmine, be up and running, bells and whistles, blue-sky laws, bottom-up management, bread and butter, break-even point, break into the market, bricks and mortar, bring home the bacon, burn your fingers, bottom-down culture,

cap and collar, cash on tap, clean bill of lading, clean driving licence, chain of command, clicks and mortar, closed-end fund, cloud on title, cold hard cash, costpush inflation, cut-throat competition, cutting-edge technology,

dead cat bounce, dirty bill of lading,

egg-timer meeting,

factory-gate price, fall from grace, fast-moving consumer goods, fill or kill, firesale price, first-tier shares, flight to quality, floor price, foreign currency translation, free flow of funds, free-rein leadership style, from rags to riches, front-of-mind brand, fully-fledged company, get in on the ground floor, go-go fund, go into liquidation, go into partnership, go under a hammer, go with the flow, grease somebody's palm,

haemorrhage red ink, hands-on experience, hard-core unemployment,

have a short position in dollars, have sticky fingers, head of the department, holein-the-wall, hot-selling product,

in high places, in private hands, in top/low gear, 
jobs for the boys,

keep a tight rein on, keep your head above water, knock on/at the door,

lean and mean organization, lender of last resort, line of command, line your pockets, live from hand to mouth, long-tail claim, low-end product, lump-sum payment,

make ends meet, make or break, make-work job, me-too product, mom-and-pop business, money at long, mover and shaker,

no-frills airlines,

off-the-books payment, off-the-peg product, on the house, open-door policy,

over-the-counter trading,

pay on the nail, people of independent means, peppercorn rent, play the first/second fiddle, ploughed-back profit, put a log on, put your hands in your pockets,

race to the bottom, real-estate bubble, run into difficulties, run on a bank, run on the dollar, rock-bottom price,

safe-haven currency, send under separate cover, shop floor worker, shortlisted candidate, show of hands, sit on a goldmine, sky-high price, steer a middle course, straight line method, super sinker bond, surrender an insurance policy, sushi bond, swallow price increases, tailor-made services, take over the reins, the rank and the file, throw money down the drain, top-hat pension, top-line goods, trailing spouse benefit, triple bottom line,

wage-price spiral, wheeling and dealing, white-shoe firm, widow-and-orphan stock, work long hours, work unsocial hours, worst-case scenario.

\section{Classification of popular business metaphors according to the underlying concept}

In English for business communication we can distinguish several semantic classes of metaphors. Examples of popular high-frequency metaphors (other than those presented above but excerpted from the same source) are divided into five groups according to the criterion of the literal meaning of the concept underlying a given metaphor.

- Metaphors of war, fight and rivalry: advertising blitz, advertising campaign, alliance, allies, attack, be on the prowl, beat the competition, bullet loan, campaign, careers officer, carpet bomb, chain of command, challenger, Chief Executive Officer, Chief Financial Officer, competitive edge, cut-throat competition, defense, defensive stock, fight, fight against pollution, fight for customers, fire, freelancer, headhunter, headhunting, headquarters, hostile takeover, industrial espionage, job hunter,

Lady Macbeth strategy, line of command, meet the target, mission, mission statement, operations, operational plan, potential recruit, press officer, prey, price war, promotion campaign, recruit, recruiter, recruitment, 
sales target, strategic alliance, strategic goals, strategic partner, strategic target, strategy, surrender, survive,

tactics, target, deal, task force, tax war, think tank, trade war, trigger sales,

war chest.

- Game and sports metaphors:

blow,

challenger, contender,

fast tracker, front runner,

game, game plan,

hurdle,

industry leader,

key player, knock-out,

lead the field, leader, leader price, leading-edge technology, level playing field, lightweight entertainment, local/global player, lose sales,

management game, market leader, market follower,

outsider,

play hardball, price leader,

race, rules of the game, runner,

smooth sailing, stakeholder, stakes are high,

take a huge leap, team leader, team player,

win a new market, winner, win-win negotiations.

- Body, health and medicine metaphors:

baby bond, blood money, blood, sweat and tears, bloodletting, body language, brain drain, brainstorming, brainwash,

cash injection, clean bill of health, collapse, company doctor, congested market, cut prices to the bone,

earmark, economic growth, economic recovery, eyeballs,

face value, facelift, fresh blood,

growth stock,

haemorrhage, hands-on experience, head of the department, headed paper, healthy economy, healthy profits,

incubator, infant industry, invisible hand of competition,

lean management, lean production, lean year,

make a recovery, mind map

new blood,

organic growth,

poison pill, product lifecycle,

recover, recovery,

show of hands, slim majority, spin doctor, suffer losses, suicide pill, swallow up a company, viral marketing,

weak economy, word of mouth.

- Colour metaphors:

be in the black, be in the red, big blue, black economy, Black Friday, black gold, black hole, black knight, black market, black marketer, black Monday, black Thursday, blackleg, blacklist, blackmail, Blue Book, blue chips, blue-collar workers, bluesky laws,

blue-sky thinking, blueprint, brown goods, brownfield site, 
create green jobs,

evergreen contract,

go green, golden boot, golden coffin, golden-collar workers, golden hallo, golden hammer, golden handcuffs, golden handshake, golden life jacket, golden opportunity, golden parachute, golden scenario, golden share, green audit, green campaign, green campaigners, green card, green currency, green energy, greenfield site, green-light, greenmail, greenshoe option, green shoots, greenwashing, grey goods, grey market, grey pound, grey power,

pink-collar workers, Pink Pages, pink pound, pink sheets, pink slip,

red carpet, red chip company, red-circling, red goods, red herring, red ink, red tape,

silver parachute,

white candlestick, white-collar crime, white-collar workers, white goods, White House, white label product, white knight, white pages, white paper, whitewash,

Yellow Book, yellow knight, yellow pages, yellow sheets.

- Animal metaphors:

bear market, bull market, bulldog bond,

cash cow, copycat product,

deer market, dog,

Economic Tigers,

fat cat,

gazelle company, gorilla,

lame duck, loan shark,

pet,

rat race,

shark, shark repellent, snail mail, stag, supercat,

turkey,

watchdog, wildcat, wildcat strike.

It is difficult to classify all metaphors used in the language of business communication into specific groups based on their underlying concepts. The list above, however, shows that the majority of the metaphors used in English reflect the concept that business is fight, war, battle, risk and rivalry on the market. Another popular class of business metaphors refers to business dealings perceived as game and sports. The number of body, health and medicine metaphors that refer to either a company, a market or an economy is also impressive.

The target domain we want to understand and present in a metaphorical way is either 'business' or 'business dealings' or 'business organization'. The source domain (e.g. fight, competition, game) is a way of presenting human experience accumulated over time and it tells us how difficult and competitive business has been in the Western world.

\section{Selected characteristics of business metaphors}

First, three important characteristics of metaphors need to be mentioned here: (1) metaphors allow for semantic compression of a given utterance, (2) some metaphors are good examples of universality of human thinking and (3) most metaphors are culture specific and language specific. 
People generally follow the principle of economy when using language and some metaphors can indeed be used as tools of conveying compressed meaning. The principle of language economy can be exemplified by comparing the following two pairs of utterances:

- In 2009 they went public.

- In 2009 they changed the legal structure of the company i.e. transformed it from a private limited company into a public company by issuing shares and offering them to the general public for the first time in their history.

and:

- a business park

- an area of land where many companies have their buildings.

These two pairs if utterances show that by using metaphor we can compress the meaning of a phrase or even a sentence and additionally make our language more expressive, e.g. business angel, Black Friday.

The language of business communication contains numerous examples of universal metaphors that appear in many languages, e.g. those that show business as a fight or war. With figurative expressions people can convey the image of business dealings as fighting with competitors to win a market.

It is interesting to learn that some military metaphors used in business English are also very popular in other languages e.g. business Polish and Russian. English military metaphors, e.g. advertising campaign, promotion campaign, long-term strategy, mission, price war, strategic alliance are also used as exactly the same metaphors in Polish, Russian and, most probably, in other European languages as well. The universality of metaphors of fight and rivalry in these languages probably results from the fact that the European and North American world of business has always been competitive and indeed fighting with rivals is often a key determinant of a business success.

It needs to be stressed that metaphors are always connected with culture and mentality. There are metaphors which may be difficult to understand for non-native speakers because of differences in values, beliefs and the way of thinking. If, for instance, business is believed to be more partner-oriented than transaction-oriented, then we may expect metaphors showing business as a long-lasting relationship and mutual trust rather than fight. Business partners will be treated as friends ready to support each other. Without knowledge of culture and traditions it is difficult to understand, learn and use some metaphors in a foreign language. If we do not share the same values and beliefs, we are not mentally ready and willing to use the metaphors whose underlying concepts are totally strange to us. This may pose a challenge to both business English teachers and learners.

Many metaphors are language specific. They can be used in one language only or in one group of languages. The fact that some metaphors are language specific supports the idea that people think in words and make intellectual use only of words or word combinations that are accessible in their mother tongue. It is worthwhile to quote H.G. Widdowson's opinion that language "signs are arbitrary, and can therefore provide for abstraction: they enable us to set up conceptual categories to define our own 
world. It is this which enables human beings to be proactive rather than reactive: language does not just reflect or record reality, but creates it. Of course, the languages of different communities will represent different variants of reality, so the explanation of experience is a matter of cultural custom and linguistic convention" (H.G. Widdowson 1996: 17).

One of the characteristic features of business metaphors is that many metaphors are expressed by extreme and dramatic adjectives (cut-throat, exorbitant, galloping, hard, massive, prohibitive, rocketing, sky-high); there are also numerous metaphors using colours (especially black, blue, red, green, white, golden, e.g. black market, blue chips, red tape, green energy, white knight and golden handshake). The former suggests high emotional impact of metaphors, while the latter reflects the importance and symbolic value of colour when labelling things. For instance, in western Europe and North America white is the colour of innocence and black is often the colour of evil (something negative, e.g. Black Friday or illegal, e.g. black market). In the western hemisphere angels are white and the devil is black. In Japan, however, white is associated with death. In China red is the colour of weddings and good luck, while in Europe it symbolizes danger, e.g. red light (R. Trim 2007).

It should also be noted that metaphors nourish and stimulate our imagination. Therefore they have great commercial value and they are often used in communication between a seller and a prospective buyer, i.e. in sales pitch. Customers are persuaded to buy products that are user friendly, sophisticated, up-market, top-of-the-range, state-of-the-art, based on the latest cutting edge technology which is green, energy saving, and environmentally friendly.

For the same reason metaphors are also used in communication between a producer and a potential customer, i.e. in the language of advertising and promotion. Advertising slogans frequently use figurative expressions, e.g. LG-life's good!, Toshiba - in touch with tomorrow, Skoda - simply clever, or Rossignol - pure mountain company. This way they can better stimulate potential customers' imagination and make a greater impact on their buying decisions. They can create a highly emotional attitude of a prospective customer towards a product or a brand. Additionally, they can convey more meaning than literal expressions used in advertising slogans.

Advertising slogans containing metaphors can promote a brand in a more suggestive and more powerful way. As a result, people tend to remember such advertisements better. A favourable brand image can be created faster provided the metaphor used in a slogan conveys additional attractive information about the advertised brand. As a result of an advertising campaign which skillfully makes use of metaphors in slogans, sales volume may increase significantly. It is therefore justifiable to claim that a clever use of metaphors in advertisements may translate into better brand recognition and, ultimately, into higher profits. The same refers to the language of sales pitch.

\section{Metaphors in business press - a corpus study}

Metaphors are extremely popular in business magazines and journals. However, they are by no means confined to the language of journalism. They are also quite popular 
in many types of oral and written texts used in business communication. In very formal business texts, e.g. trade contracts, official business letters or reports, metaphors are relatively rare. Yet, one can find such popular metaphors as for instance: $C E O$, bad loans, leverage, targeting, product life cycle, product portfolio, strategy, mission, head office or headquarters even in extremely formal documents.

A small non-representative corpus of business articles published in the Wall Street Journal of 25 February 2015 was examined by hand and many interesting examples of figurative language were found there. The total number of metaphors found in the articles in that single issue exceeded 250 items. Some of them are well-established in the language of business communication (so called lexicalised, standard or 'dead' metaphors), while others are original and brand new (novel or 'living' metaphors). It is difficult to predict which of these new and still considered novel metaphors will be used in the future; some will probably have an extremely short life span.

Metaphors come and go. In the language of business communication, we can witness many lexicalised metaphors that have been used for years (e.g. face a challenge, cut prices, or sky-high prices). Today language users treat them as standard expressions forgetting that the literal meaning of e.g. 'cut' has been replaced by a figurative meaning. We can witness many new metaphors that enter language every day. Only some of them are likely to be in general use for years to come, others will never be used again.

The list of 'living' metaphors excerpted from the Wall Street Journal corpus (25 February 2015), which is presented below, is by no means complete and includes only two selected conceptual categories, namely:

- metaphors of war, fight and rivalry:

come under fire, defeat for democracy, derail demand, enter rough political waters, EU executive arm, fight together to confront shared threats, put an economic gun to its own head, sparkle panic, standing up for the allies, triggered a diplomatic uproar, triggered a violent reaction, try similar tactics, veteran of the Obama campaign.

- metaphors of body, health and medicine:

backbone of the common currency, blistering report, bruising battle, flood of flu, heal the wounds, market is being hurt, mix of insulin and sugar, options are painful, palpable anxiety, inject massive doses of stimulus, injected Nazi-era grievances, recovery room, states seem immune to, the war is the health of the state.

The list above shows that business journalists are very creative in inventing new metaphors (e.g. mix of insulin and sugar, blistering report). They are also ready to experiment with old metaphors used in a new context (e.g. trigger a diplomatic uproar, derail demand). If the Wall Street Journal readers know the figurative meaning of trigger, they find it very easy to understand the meaning of a new metaphor in a new context.

Not only journalists but also politicians, scientists and celebrities create metaphors. The famous metaphor of the iron curtain was coined by Sir Winston Churchill, Iron Lady was a product of a Russian newspaper, and the road map metaphor was invented by the US army officers during the Gulf war. Product life cycle was introduced by the Boston Consulting Group specialists. Sometimes metaphors are created 
to name something new and important in a figurative way, e.g. a relatively new metaphor housing bubble is a product of the 2008 financial crisis, political tsunami appeared after the tsunami attack in Asia in 2009 while fiscal cliff is connected with the US budget deficit in 2013 (the metaphor was popularized by Ben Bernanke).

\section{Discussion}

Using metaphors adds authenticity to the language of business communication and enriches it. One fundamental question, however, that non-native speakers of English need to ask is what kinds of metaphors and which specific metaphors to use. It seems justified that only the metaphors that are well-established in the language of business communication should be used. Such well-established metaphors, which are no longer perceived as metaphors (e.g. we are open to suggestions, face a risk, head office, head of department, make an offer, cash injection, lower the price), deserve incorporation into the language of business communication. Non-native speakers are exposed to a variety of metaphoric expressions in authentic business texts. However, it seems reasonable that they should use the most popular, so called 'dead' metaphors only and try not to experiment with 'living' metaphors.

Business English users who are non-native speakers of English may sometimes find it difficult to understand and use some elements of figurative language. Many L2 users find it quite easy to recognize the figurative meaning of metaphors, yet some are not sure about the context in which a given metaphor can be used. As a result, they refrain from using metaphoric expressions, especially multi-word ones which are more difficult to remember. They also tend to avoid those metaphors that do not resemble the metaphors used in their mother tongue.

Sometimes non-native business English speakers cannot understand a metaphor because the words in it are from a different area of ESP. For instance health metaphors used in business communication may be difficult to understand because of medical vocabulary items they contain (e.g. 'backbone', 'blister', 'bruise', 'palpable', 'recovery room' found in the Wall Street Journal corpus). These vocabulary items are perfectly well understood by all native speakers (not only by medical professionals), yet they may be problematic for non-native business English users. It seems to suggest that poor knowledge of non-business vocabulary may be an obstacle to understanding some metaphoric expressions.

Metaphor is often treated as a peripheral rather than central part of language description and language instruction (F. Boers 2000). Metaphor is, however, a natural and frequent component of business communication and it deserves attention. The paper presents about 500 most popular 'dead' business metaphors and classifies them according to (1) their formal structure and (2) the concept underlying a given metaphor. It is hoped that the presented categorization of popular metaphors may be helpful in a better description of business English. It is also hoped that the paper may contribute to increased awareness of the importance of figurative language in business. Further studies are needed to better analyse and understand the role of metaphors in business communication. 


\section{Bibliography}

Boers, F. (2000), Metaphor Awareness and Vocabulary Retention. In: ELT Journal, 21, 553-571.

Cambridge Business Dictionary and Thesaurus. (http://dictionary.cambridge.org/dictionary/business-english; accessed 10.05.2016].

Cortazzi, M./ L. Jin (1999), Bridges to learning: Metaphors of teaching, learning and language. In: L. Cameron/ G. Low (eds), Researching and Applying Metaphor. Cambridge, 149-174.

Cameron, L./ G. Low (1999), Researching and Applying Metaphor. Cambridge.

Henderson, W. (2000), Metaphor, economics and ESP: Some comments. In: English for Specific Purposes, 19, 167-173.

Lakoff, G./ M. Johnson (1980), Metaphors We Live By. Chicago.

Lewis, M. (1997), Pedagogical implications of the lexical approach. In: J. Coady/ T. Huckin (eds), Second language vocabulary acquisition. Cambridge, 273-290.

Littlemore, J./ G. Low (2006), Figurative thinking and foreign language learning. Hampshire.

Long, M./ J. Richards (1999), Series editors' preface. In: L. Cameron/ G. Low (eds), Researching and Applying Metaphors. Cambridge, $\mathrm{x}-\mathrm{xi}$.

Longman Business English Dictionary (2007). Harlow.

Oxford Collocations Dictionary (2008). New York.

Richards, J./ R. Schmidt (2002), Longman Dictionary of Language Teaching \& Applied Linguistics. Harlow.

Thornbury, S. (1991), Metaphors we work by: EFL and its metaphors. In: ELT Journal, 45 (3), 193-200.

Trim, R. (2007), Metaphor Networks. The Comparative Evolution of Figurative Language. New York.

Widdowson, H.G. (1996), Linguistics. Oxford. 